\title{
'Coloured' Consciousness: Reflecting on How Decoloniality Facilitates Belonging
}

\section{Danille Elize Arendse \\ ORCID iD: https://orcid.org/0000-0002-8368-8749}

\section{Abstract}

This article undertakes an existential journey by exploring the author's experience of being classified as a 'Coloured' woman in South Africa, as per its legislation pertaining to classification, and the reflections that have emerged from it. The author's lived experience during post-apartheid South Africa has demonstrated that there are damaging internalised knowledges pertaining to her identity as a 'Coloured' woman, some of which require active decolonising. These reflections were particularly important after attending the 2020 Decolonial Summer School at the University of South Africa in Pretoria, South Africa. It was through the identification and recognition of her layered oppression and her complicity in this oppression that she found the courage to dismantle practices of subordination that were not serving her purpose of being in the world. Through the use of a dialogue format, she reflects on the inhumanity she encountered with her legal classification and how it has shaped experiences she has had in different contexts in South Africa. She also contrasts these experiences with the experiences she has had with the UNISA conference (noted above) members that transitioned their thinking and understanding of her. The replication of coloniality and apartheid through the 'Coloured' classification demands that we become conscious of practices that dehumanise us, lest we become second-hand agents of colonisation ourselves. Through engaging with decoloniality, she terms 'Coloured' consciousness as a form of critical awareness of her legal classification as 'Coloured' and how this consciousness allows her and others classified as such, to take back their agency and shift their agency in more constructive ways. More importantly, this 'Coloured' consciousness speaks to decolonising and re-humanising 'Coloured' women whose intricate 'Blackness' has been shaped by colonialism, apartheid and 
violence. It is hoped that this engagement with 'Coloured' consciousness will offer a critical awareness of 'Coloured' identity in South Africa and internationally.

Keywords: 'Coloured', consciousness, colonising decolonial, decolonising, humanity, women

\title{
Introduction
}

\begin{abstract}
All our present struggles with respect to race, class, gender, sexual orientation, ethnicity $\ldots$ the sharply unequal distribution of the earth resources ... these are all differing facets of the central ethno-class Man vs. Human struggle (Wynter 2003: 260 - 261).
\end{abstract}

When reflecting on Sylvia Wynter's quote above (2003: 206 - 261), her emphasis on the humanity of those deemed as inferior is evident. In her work, Sylvia Wynter demonstrates that those that have been racialised as inferior to the white man, who is considered the standard embodiment of humanity, would always be caught up in a struggle to assert their humanity. This struggle to be recognised as fully human is still evident in present day South Africa. Although colonialism and apartheid has 'ended' in South Africa, those that have been racialised as non-white continue to engage in struggles to reclaim their humanity. This struggle is multidimensional in nature and is interlocked in the race, class, gender, sexual orientation and ethnicity intersections of non-white persons. During the colonial period in South Africa, many enslaved people from Indonesia, Malaysia, India, Madagascar, East Africa and West Africa were forcibly brought to Cape Town by the Dutch and Portuguese colonisers for labour power (Isaacs-Martin 2018; Maart 2014b; Adhikari 2006, Ahluwalia $\&$ Zegeye 2003; Martin 1998). These enslaved people were also coerced into sexual relations with European and Portuguese settlers and this resulted in what became termed as miscegenation. Miscegenation refers to the offspring from sexual relations between different race groups. This form of sexual relations was not limited to the enslaved but also included coerced sexual relations between European and Portuguese settlers with the indigenous population of 
South Africa (Khoisan, Griqua, Namas). The offspring resulting from the latter were considered racially mixed and thus a need started developing to limit such people from multiplying. It is also worth noting that there were sexual relations between the enslaved populations and the indigenous Khoi, San, amaXhosa, Griqua and Namas that also produced offspring with varied racial features. Since these sexual relations became a concerning trend, the visiting commissioner of the Dutch East India Company (DEIC) to Cape Town in 1685 made a ruling that white men caught engaging sexually with enslaved women would be punished to work as slaves for a period of six months to a year. During 1795, the British, having fought against the Dutch, succeeded in governing Cape Town and continued this racial segregation. In the 1900s, there were several practices of excluding black people from entering the cities, two of which took the form of the Native Reserve Location Act of 1902 and the School Board Act of 1905. In this manner, racial segregation was encouraged. This historical build up in South Africa of racial segregation led to the formation of the National Party's victory and the start of the formal apartheid government in 1948. Apartheid was premised on separating the races and furthering White supremacy (Maart 2014a; Ahluwalia \& Zegeye 2003).

In South Africa, although apartheid had legalised racial segregation and created a system of legal classification for races, colonialism was carried out by keeping races separate and ensuring white settler domination. Apartheid therefore sought to extend and formalise the previous forms of racial segregation observed during colonisation. The offspring of miscegenation had multiplied and created a racially mixed group of people whose physical features were diverse and varied. Since the apartheid government was focused on social control, they devised a 'divide and rule' strategy that sought to divide all the races formally and legally. Their only difficulty was with the racially diverse offspring of miscegenation that was too complex to categorise as a race group. This led to several attempts at racialising those with racially diverse features into racial categories. The then government's final attempt took the form of homogenising the racially diverse group into a single category labelled 'Coloured' and this became the legal classification of a group of people who were descended from the previously enslaved, from Malaysia, Indonesia (the region of Java, in particular), Bengal, neighbouring countries such as Angola and Mozambique and various indigenous groups of people. Since the apartheid government legalised racial segregation, any sexual relations between different racial groups were prohibited and thus, the very existence of the legal classi- 


\section{Danille Elize Arendse}

fication was scorned and met with disapproval. To discourage further sexual relations and to ensure minimal growth of the 'Coloured' population, the racially diverse physical features exhibited by those belonging to this group were regarded as negative and inferior (Isaacs-Martin 2018; Maart 2014b; Adhikari 2006; Ahluwalia \& Zegeye 2003; Martin 1998). Through this, the apartheid government effectively separated the black and 'Coloured' groups from forging solidarity as the 'Coloured' population was plagued with psychological indoctrination that they were inferior, pessimistic and essentially less than human. This caused the 'Coloured' population great turmoil which is still evident in post-apartheid South Africa today.

\section{Methodology}

This article offers a reflection of my existential questions and concerns pertaining to my 'Coloured' identity, which become evident during and after attending the 2020 Decolonial Summer School in Pretoria, South Africa, organised by a team from the University of South Africa (UNISA). The presenter team was composed of, among other, professors Gordon, Maart and Ramose, whose work I engage with in this article (Gordon 2020a, b; Maart 2020a, b; Ramose 2020). The UNISA Summer School allowed me to reflect on experiences I have had because of my legal classification as a 'coloured' woman in South Africa.

The methodology used in this article takes the format of a verbal and written dialogue. This allowed me to reflect on specific questions posed to me by my mentor, Rozena Maart. These questions were designed to elicit my thoughts and knowledge on 'Coloured' identity in post-apartheid South Africa. In this dialogue, I specifically draw attention to how I as a 'Coloured' woman have become subject to acts of inhumanity through the persistent enactment of the legal classification of 'Coloured' upon my being by my colonisers.

This article is also focused on examining the emergence of a 'Coloured consciousness' within me. I define 'Coloured consciousness' as an awareness of being legally classified as 'Coloured', the impact of that awareness and the racial tropes that were created to inflict a false sense of humanity assigned to those legally classified as such, in other words, racial tropes that perpetuate a false consciousness of a people yet dependent on the labour of those very people to build a city for the settler colonials and take care of their offspring. For the purpose of this article, the term, 'coloured' has been written in inverted 
commas to draw attention to it as a legal classification assigned to persons identified as neither white nor black. I endeavour to create a consciousness of the racist classification of 'Coloured' and how insidious the construction and continuation of 'Coloured' reproduces sub-humanity. The awareness of this reproduction of inhumanity should create what I have termed, 'Coloured' consciousness. This consciousness advances the critical use of 'Coloured' in scholarly avenues where we have witnessed the careless use of racial classifications in publications (such as we have in Niewoudt et al. 2019) in South Africa.

I attribute 'Coloured' consciousness to the learning and teaching experienced at the 2020 Decolonial Summer School in which I observed how decoloniality facilitated a sense of belonging. The discussions on decoloniality created a consciousness and an understanding that transcended the restrictions of racial classifications towards a black unity, thereby embracing our innate humanity (Gordon 2020a; 2020b; Maart 2020a, 2020b; Ramose 2020; 2019). It is my hope that my reflections on my legal classification of 'Coloured' opens further debates on race, the continued process of racialisation and the plight toward humanity in post-apartheid South Africa. I now turn to the dialogue segment of this article.

\section{Being 'Coloured' can be Problematic}

MAART: Danille, can you share with us what your identity means to you?

ARENDSE: I believe that as one grows into oneself your identity becomes more important to one. To me, identity means how I define myself. When reflecting on who I am during the Decolonial Summer School, an important event occurred to me. Regardless of who I thought I was, what I was being perceived as has had a greater impact on me compared to who I defined myself to be. This was imperative to me, as people tend to respond to one based on what they see. This has been true for me in South Africa as I have been instantly recognised as 'Coloured' in most contexts; I utilise the phrase recognised not because I was known to the seer but because my physical features were known. However, there have been instances when I have not been recognised as 'Coloured' and these instances have provided me with food for thought. Perhaps, my appearance was not after all, just 'Coloured', I thought on occasion. This led me to think of why being or not being 'Coloured' mattered 


\section{Danille Elize Arendse}

to me. Having said this, I believe that my identity has not been static but has evolved as I have grown in different areas of my life and in terms of the knowledge I have been exposed to regarding myself and the history of South Africa. In essence, I don't believe I can separate my identity from South Africa - the emergence of my identity - as its history has impacted on how I understand myself. The history of South Africa has influenced how I understand my physical appearance and the way I speak. There are so many aspects of my identity that I believe are tied to my South African heritage.

MAART: What does it mean to be 'Coloured'?

ARENDSE: I only truly started thinking about being 'Coloured' when I attended a historically black university. It was the first time I was taught by black and 'Coloured' educators. It was also the first time, besides the neighbourhood where I lived that I was surrounded by black and 'Coloured' people as the majority. My interaction with specifically 'Coloured' individuals during my university allowed me to rethink my racialised identity. In previous spaces of learning, I was educated by white people and they had not taught or allowed me to question my identity as a 'Coloured' woman. In my university space, I felt more accepted and this allowed me to feel connected. There was a sense of familiarity with the 'Coloured' people in this space that I had not known but felt instantly [connected to]. So to address your question, prior to university, I had not really thought about my identity as 'Coloured'. I accepted it as a fact of life. I was 'Coloured' and that was it, nothing more.

MAART: When did you become conscious of what being 'Coloured' means to you?

ARENDSE: It was only at university that I truly became conscious of what being 'Coloured' meant to me. Through the development of my years of consciousness over the years, the meaning I attach to 'Coloured' has changed. For me, in this present day, 'Coloured' does not signify a race group, instead it signifies an ethnic variety and a plurality. 'Coloured' speaks to a culture of people that are so varied but similarly share a history of colonisation and oppression through the suppression of their varied ancestry. I love that when I speak of 'Coloured' now, I mean plural heritage. 
MAART: Can you talk a little about when you first understood what the term 'Coloured' meant?

ARENDSE: When I was young, I understood 'Coloured' as my race group and the way in which I identified myself on all documents both at school and anywhere where that information was requested; it was usually asked for demographic reasons. Then there was also my consciousness of 'Coloured' during my university years when occasionally reading material on 'Coloured' identity. I started to form a clearer idea of what the term 'Coloured' actually meant. As such, if I had not endeavoured to read further on 'Coloured' history and identity, I would have only thought that it was a race group. After my readings, I now understood the term 'Coloured' to mean that I belong to diverse ancestry. The term originated during apartheid when the regime tried to classify people born from diverse ancestry where offspring was considered to be of a different race group. In this sense, I have come to understand 'Coloured' to mean racial diversity and the combination of different cultures and racialised identities.

MAART: Has it been a problematic term for you? If so, can you tell us why?

ARENDSE: When I relocated to a different region than where I was raised and took my undergraduate degree, I felt more invisible and simultaneously highly visible because of my appearance. In Pretoria I hardly saw 'Coloured' individuals. At work I was one of two 'Coloured' individuals depending on the year, as sometimes I was the only one. Over time, I became accustomed to the absence of 'Coloured' people in the region. It was however in this region, due to the lack of 'Coloured' people, that some people struggled to place me into a race group. It was also in this region that I became conscious of my appearance in a very different way. My acknowledgement of my legal classification, 'Coloured' then became a means through which people would communicate the stereotypes and false truths they had heard about 'Coloured' people. This would place me in the awkward position of having to either deny these stereotypes or accept them and laugh them off. On the first few occasions, I would laugh and acknowledge that there were such stereotypes but I did not believe in these stereotypes. Later, when the occasion arose, I felt the pressing need to resist any acknowledgment of 'Coloured' being tied to specific stereotypes. I also felt a growing frustration towards people placing and 


\section{Danille Elize Arendse}

restricting my identity according to 'Coloured' stereotypes. It also became part of my defence that I could and would not speak for all 'Coloured' people when I appeared to be the only one in the room or in the conversation. Against this backdrop, I have become conscious of my appearance and how people perceive me. I have also become aware that due to stereotypes and my appearance, some people will not gravitate towards me but instead see me as a potential opponent. I say this in light of being unable to find solidarity with fellow black women, as my appearance and the stereotypes of my legal identity at times, appear to hinder solidarity with black women. It is through these experiences that 'Coloured' has become problematic for me, especially since it is a legal classification used for all legal documents. The legalisation of the term 'Coloured' obscured the fact that it was a social construction and not an actual racial classification. This has resulted in the persistence of negative perceptions and increased the uncritical use of the term_ 'Coloured' in various contexts in South Africa. The very existence of people labelled as 'Coloured' are still considered to be problematic due to colonial and apartheid-informed notions of what it means to be human (Gordon 2010; Wynter 2003; Fanon 1986). This allowed me to question why being a 'Coloured' woman complicates the expression of my humanity. Are we not still perpetuating degrees of inhumanity in South Africa by condoning the use of 'Coloured' as a racial classification? More importantly, why were white men and white women able to deem our humanity as sub-human by labelling us as 'Coloured' (Ramose 2019; Gordon 2010; Wynter 2003; Fanon 1986)? Why did they feel they had this authority to name us (Ramose 2019)?

\section{The Dangers associated with Coloniality in post-Apartheid South Africa}

MAART: Having listened to you talk about your journey, what kind of history does the term Coloured carry for you? I want to be clear in how I utilise the term Coloured. It is a politically charged word for some: to me it signifies a racial classification that was imposed but became an ethnic and cultural identity that people from my community came to embody and give life to. I identify as Black. I also identify as Coloured. I regard my ethnic and cultural identity as Coloured and I do not place it in inverted commas as unreal, false, imagined, or non-existent. I think people have various reasons for placing the term Coloured in inverted commas, some of which are to indicate that it is a 
social construction. I am not here to doubt or cast judgement on those reasons. I prefer to state what mine are, from the outset.

ARENDSE: The history associated with 'Coloured' is related to two particular laws ratified during apartheid, namely: The Prohibition of Mixed Marriages Act of 1949 and The Immorality Act of 1950, which prohibited interracial relations and thus those born from such sexual relations, were negatively perceived by White supremacists. Since 'coloured' men and women were born from this miscegenation, they were automatically regarded as illegal and negative traits were associated with their appearance (Isaacs-Martin 2018; Shefer et al. 2018; Josias 2015; Maart 2014a; 2014b; Erasmus 2011; Adhikari 2006; Ahluwalia \& Zegeye 2003; Martin 1998). The apartheid government created the 'Coloured' category to maintain social control and further divisive politics among black men and women of different skin pigmentation (IsaacsMartin 2018; Erasmus 2011; Adhikari 2006; Ahluwalia \& Zegeye 2003; Martin 1998). As a result, the racial classification of 'Coloured' was legalised during apartheid through the Population Registration Act of 1950 (IsaacsMartin 2018; Maart 2014b; Erasmus 2011; Adhikari 2006; Ahluwalia \& Zegeye 2003; Martin 1998). The apartheid government ensured that those classified under the category of 'Coloured' were made to feel inferior and their morality questionable (Isaacs-Martin 2018; Maart 2014b; Adhikari 2006; Ahluwalia \& Zegeye 2003). The injustice and contested morality associated with those classified as 'Coloured' during and post-apartheid continues to be interwoven in law and part of the justice system (Ramose 2019; Adhikari 2006; Ahluwalia \& Zegeye 2003). These laws formally introduced and legalised during apartheid have directly impacted on the term 'coloured' and how it is presently understood in post-apartheid South Africa. Although colonisation was responsible for the initial formulation of racial segregation, apartheid had legalised it and legally classified various people as 'Coloured'. In postapartheid South Africa, the continued use of apartheid classification emphasises the importance of understanding history, particularly in relation to the complex history of how 'Coloured' was termed during apartheid.

MAART: When you look back at the history of racial classification in South Africa, what does it evoke?

ARENDSE: When I think of the history of racial classification in South Africa, 


\section{Danille Elize Arendse}

it evokes emotions of unfairness and injustice. The racial and legal classification of 'Coloured' in South Africa has subjected those with this classification to a questionable humanity. More importantly, the apartheid government succeeded in exposing 'Coloured' people to fictitious narratives so that they would internalise these narratives and believe them. For me, this took the form of how I did not question my identity when I was young. I knew I was 'Coloured' and I knew this was my race group. This has been the longlasting effect that the racial classification has had in South Africa. Having said this, racial classification has impacted on the conditions under which 'Coloured' people have been racialised which have determined their materiality. The racial classification can therefore be viewed as a system of oppression through which the humanity of those deemed non-white were constantly contested. These racial classifications feed into racial tropes that have become inescapable. The premise of colonisation and apartheid was to ensure the separation of races, and consequently, this racial divide was justified and promoted the dehumanising of those viewed as objects (non-white), because only the 'settler' (white) or the 'coloniser' could be subjects and fully human (Boswell et al. 2019; Snaza \& Tarc 2019; Maart 2020a; 2020b; 2014a; Josias 2015; Mendez 2015; Lugones 2010; Adhikari 2006; Ahluwalia \& Zegeye 2003; Wynter 2003). For this reason, the history of violence is an inescapable reality for 'Coloured' men and women in South Africa. Although colonisation and apartheid have ended and we are in a democratic postapartheid period in South Africa, 'Coloured' men and women still face violence, but in the form of epistemology and ontology (Ramose 2019, Boswell et al. 2019; Snaza \& Tarc 2019; Shefer et al. 2018; Mendez 2015; Maart 2014a, b; Gordon 2010; Lugones 2010; Adhikari 2006; Ahluwalia \& Zegeye 2003; Wynter, 2003). This epistemic violence is particularly rife in the continued use of racial classifications in South Africa that still unconsciously feed into the hierarchical position of races and that 'Whiteness' is still superior and 'Blackness' inferior.

MAART: You and I discussed the research undertaken by a group of scholars from the University of Stellenbosch. What are some of your critiques of that process?

ARENDSE: The research published by the University of Stellenbosch scholars caused quite a stir in both academic and media circles. To me, the research was 
framed in a manner that endorsed historically pessimistic connotations associated with 'Coloured' women. The title, 'Age- and education-related effects on cognitive functioning in Coloured South African women' (Nieuwoudt et al. 2019), alludes to the classification of 'Coloured' as an actual racial category and ignores the historical and contextual factors associated with the social construction of 'Coloured' (Boswell et al. 2019; Dalmage 2018; Shefer et al. 2018). To be honest, when reading the title, I was already alarmed. This was further supported by the abstract that made conclusions based on a small sample of 60 women. There were other aspects such as the following quote, 'Young to middle-aged Coloured women present with low cognitive function and which is significantly influenced by education' (Nieuwoudt et al. 2019: 1). This quote suggests, as does the title, that 'Coloured' women, on the whole, as race group are problematic. It furthermore suggests that they are cognitively delayed and that their education has impaired their cognitive functioning. In just this short quote, the race, gender, legal classification, cognitive functioning and education of 'Coloured' women are interlocked in their oppression. The research also echoes previous narratives associated with 'Coloured' women as inferior to the white norm. This research did not account for the historical effects of colonisation and apartheid on 'coloured' women which deliberately disadvantaged them in terms of how they were racialised, their education, physical location (forced removals), relationships and freedom of movement. For me, this empirical study emphasised the need to critically engage with the social construction of 'coloured' women. It demonstrated that in 2019, there were still prevailing racist and sexist notions of 'Coloured' women in South Africa and this knowledge was being presented as scientific evidence. This motivated me to engage with my legal racial classification as a 'Coloured' woman. The research by Niewoudt et al. (2019) highlighted how 'Coloured; women had been essentialised through racist ideology and this to me, was highly problematic, considering the inherent heterogeneity from my varied ancestry (Boswell et al. 2019; Shefer et al. 2018; Maart 2014b; Adhikari 2006). I was pleased that the article was eventually retracted after a petition was sent to the publishers of the journal. This research, however, presented me with an opportunity to dismantle harmful knowledge practices that persistently perpetuate racism and sexism onto 'Coloured' women in post-apartheid South Africa. I did not want to justify my existence or humanity to the oppressor; instead I wanted to challenge prevailing knowledge on 'Coloured' women such as myself. 
MAART: You noted how the Decolonial Summer School of 2020 got you thinking about your Coloured identity. Can you share some of those thoughts?

ARENDSE: The Decolonial Summer School raised a consciousness within me and allowed me to ask myself a few questions related to my identity as a 'coloured' woman [most of which I have tried to cover in this article]. It allowed me to get a greater understanding of what decoloniality means and its application in my life. I understood decoloniality to mean that there are colonial remnants still evident in the modern world. Moreover, our knowledge and way of being has and continues to be influenced by coloniality. For this reason, there needs to be an intentional interrogation of colonially informed knowledge and its impact on identities today (Gordon 2020a; 2020b; Maart 2020a; 2020b; Ramose 2020; Mendez 2015; Lugones 2010; Wynter 2003). In my case, I solely focus on how coloniality continues to permeate the identity of 'Coloured' women such as myself and why decolonization of 'Coloured' as a legal classification is imperative. The experiences I had during the Decolonial Summer School were instances that allowed me to revisit my legal identity as a 'Coloured' woman. In the first instance, there was a colleague of mine (black woman) that attended the school with me. We had talked at work previously but never to the extent that we could go beyond the surface. It was through the talks and the discussion of issues raised during the Decolonial Summer School that we started to form an actual connection with one another. She indicated to me, 'I didn't really know who you were but during this summer school, I am realising that we have a lot in common'. It was in this instance that I realised that we were separated by appearance but not in social justice. It also occurred to me that she was able to look past my identity as a 'Coloured' woman and see me as a black woman.

In the second instance, there were men and women from Brazil in attendance at the Decolonial Summer School. It was strange that although I had nothing in common with them, I had noticed their appearance and felt that there was something similar among us. During one of the discussions, the one Brazilian woman noted, 'I see myself as a Black woman'. This was striking to me because I realised how easily she had said it. It then occurred to me that perhaps I had internalised that I could not claim being black because of my appearance and how people had positioned me outside of the construction of black. In my interaction with the Brazilian people, they had also noticed my appearance and wanted to know where I was from. After informing them that 
I am South Africa and legally classified as 'Coloured', they understood, because they had heard about this racial classification. In later interaction, the Brazilian man however uttered something to me in Portuguese. I indicated that I did not understand, and he responded, 'I am so sorry. When I see you, I keep thinking that you are Portuguese and then I speak to you in Portuguese. It is amazing how much you look like us'. I agreed as I had also noticed the similarities in our appearance, and I understood that I meant Portuguese as one of the main spoken languages of black people from Brazil. Although these incidences are different, the interaction I had with fellow participants were important and essential for forging a decolonial future. And whilst the UNISA Decolonial Summer School of 2020 was over it was definitely not forgotten.

MAART: You once noted that being Coloured is inescapable. Can you elaborate on that statement? Is there a difference between a legalised identity, a socialised identity, and a politicised identity, which as per the latter, you take up yourself, wilfully, with the awareness that you've chosen it for yourself?

ARENDSE: I feel that in many experiences that I have had, being 'Coloured' has been inescapable. In most spaces in South Africa, I have been identified as 'Coloured' by others as well as self-identifying as 'Coloured' when people were confused by my physical appearance. This meant that wherever I went in South Africa, my legal classification as a 'Coloured' woman was a description I could not escape. In terms of the differences between my legal, socialised and politicised identity, I will elaborate on each of these. Previously, I had no need to question my legal identity as 'Coloured' because I had internalised that I was 'Coloured'. What this specifically meant to me is unclear, although it would be fair to deduce that it meant that this race group was legitimate. My internalisation of 'Coloured' also translated into the fact that I knew I could not be white or black. These racial categories were not available to me. I had learned to recognise my appearance as an integral part of being 'Coloured'. In this way, I was socialised into my legal identity. Another aspect that contributed to my internalising of 'coloured' was that I had been educated by white institutions and thus they were upholding White supremacy (Mendez 2015; Erasmus 2011; Lugones 2010; Adhikari 2006; Ahluwalia \& Zegeye 2003; Fanon 1986). My legal identity was thus upheld through my socialisation of continuously identifying as a 'Coloured' woman and others recognising and confirming my legal identity as a 'Coloured' woman. This is contrasted with 


\section{Danille Elize Arendse}

my education at a historically black institution where I experienced belonging and the need to rethink my racial identity. Due to my education at white institutions, I had internalised the apartheid category of 'Coloured' as truth and a signifier of my identity. It was only when I was confronted with alternative learning and education that I was able to identify my internalised oppression. In other words, I had not only become 'Coloured' in my appearance but also in thought. I had internalised my oppressive self as an oppressive way of being that was inherent in my origin. This, I believe, is the very danger of coloniality, as it seeks to encourage your acceptance of being dehumanised (Gordon 2020a; 2020b; 2010; Maart 2020a; 2020b; Ramose 2020; Boswell et al. 2019; Mendez 2015; Lugones 2010; Wynter 2003; Fanon 1986). Through this consciousness, I became aware of how 'Coloured' as an identity has always been used for political reasons. When identifying as a black woman, my identity becomes politicised because it acts in contradiction with my legal and socialised identity. It is, however, an identity I choose. Being black does not mean that I have not been influenced by my legal and socialised identity and for this reason; I regard 'Coloured' more as an ethnic identity.

MAART: What are some of the stereotypes that you were confronted with in the new location outside of the Western Cape and how did you tackle them?

ARENDSE: Since moving away from Cape Town to Pretoria, there has been a transition in my emotions towards how people have racialised and gendered me as a 'Coloured' woman. Stereotypes such as my hair being 'bushy' or 'very curly', and my body being stereotyped as 'you have hips and bums (sic)' were used to racialise me and gender me as a 'Coloured' woman. Through these stereotypes, my hair and body features are interpreted as negative. Interestingly, these same features are also used to separate me from black women, as my hair is 'too straight' or 'You don't have a bum' or I am 'too light'. My skin colour, hair and body shape therefore become the means by which I am both separate from blackness but still exhibit enough blackness to not be mistaken for white. There is thus an ambiguity forced upon me by others who do not know how to make sense of my physical appearance (Adhikari 2006; Ahluwalia \& Zegeye 2003). I experienced some frustration towards the persistence of stereotypes towards me and this created a shift in me wanting to actively dismantle those perceptions and stereotypes. I felt that there was an internalised stigma that men and women were projecting on me because of my 
racial classification. I become visible in spaces where there are not enough women with ambiguity and thus, I complicate the accepted racial binary of white and black. My experiences with confronting stereotypes have allowed me to identify with feelings of inferiority, oppression, shame, doubt and a lack of belonging (Dalmage 2018; Isaacs-Martin 2018; Shefer et al. 2018; Adhikari 2006; Ahluwalia \& Zegeye 2003). Consequently, these negative stereotypes had also facilitated experiences of 'Other-ing'. Through this, I constantly fluctuated between belonging and un-belonging in a context I called home (Gordon 2010). Trying to address the stereotypes meant that I needed to address knowledge of 'coloured' that was projected onto me. There was no point in upsetting myself when I realised that those who projected did not know any better; they did not fully understand how the term 'Coloured' came about nor did they comprehend the complex and varied ancestry of 'Coloured' people. For this reason, when I was irritated or frustrated by stereotypes placed on me, I would respond, saying: 'You do know that Coloured is not an actual race group, right?' It would then be up to the person to engage me further if they were interested in understanding my history and ancestry. I feel that this has been a more productive way of responding to stereotypes instead of merely opposing the use of stereotypes.

MAART: Has there been a marked difference in the way in which you experience your identity after 1994? Have you spoken to your parents and/or family members about this and do they feel that there has been a shift in the way that they see themselves or what they believe others see them?

ARENDSE: After becoming conscious of my identity as a 'Coloured' woman, I engaged both my parents and my grandfather on their experiences during apartheid and how they were treated during this period. I remember my grandfather saying that he loved swimming, but many beaches close to his home were not open to non-whites. He could alternatively swim in the very early hours of the morning as 'Coloured' people were only permitted to swim at certain beaches and during certain times. This was quite significant for me, as I love swimming, and having been fortunate enough to swim at any time or at any beach in post-apartheid South Africa. When speaking to my mother, I remember her recalling how she was paid the least [in her job] because she was both 'Coloured' and a woman. When thinking of my own employment, I have been fortunate because black and 'Coloured' women fought this oppression so 


\section{Danille Elize Arendse}

that women such as me could have a better future. In speaking with my father, he recalled how they were all treated differently because of their racial classification. It was also because of these classifications that they were limited in where they could work and in how much they could earn. Thus, as a young man, he needed to leave school and start working for his family. These remnants of poverty I can still see today, as there was no money for school and the possibility of further education was not an option my father felt was available to me. This I have come to understand by understanding the historical, political and social consequences of apartheid. After completing my Masters' degree, I saw a change in how my family members see themselves. I think they had perhaps held onto notions of apartheid that some spaces were not available to us, as 'Coloured' people. My postgraduate education symbolised that in a post-apartheid society we were able to do things not previously permitted during apartheid. Although there are more opportunities available to me as a 'Coloured' woman in post-apartheid, and I am able to reimagine my identity, I am aware that being 'Coloured' remains contentious. Thus, how others see me continues to be problematic and this is why we still battle with stereotypes that are mistaken for truths in the post-apartheid era. Post-1994, there are definite differences in the way I experience my identity compared to my parents and grandfather, but there are also similarities in how we are perceived and understood. Based on this similarity, I feel that it is necessary for me to engage with the 'Coloured' identity in our current postapartheid society.

\section{Decoloniality Dismantles Stereotypes}

MAART: What has decolonisation meant to you?

ARENDSE: Decolonisation has become non-negotiable for me as a 'Coloured' woman because it assists me in emancipating myself from the dehumanising practise of my legal classification. Decolonisation will further promote black solidarity instead of furthering the separation of the races. I believe that a prerequisite to decolonisation is a consciousness of the fictitious nature of the racial classification of 'coloured' and how it has only been employed for social control (Isaacs-Martin 2018; Erasmus 2011; Adhikari 2006; Ahluwalia \& Zegeye 2003). I draw on Maart's definition of decolonisation (2020b) in which she indicated that to decolonise, means ' ... to detach yourself 
as the colonised subject from the coloniser'. It also involves removing yourself and your behaviour from being regulated by the coloniser. As such, by decolonising myself as a perpetual victim of 'Coloured' identity, I was removing the negative emotions (inferiority, oppression, shame, doubt and a lack of belonging) associated with accepting this regulation over me. In my refusal of this legal classification as a signifier of my racial identity, I was not only decolonising myself, but actively transforming who I wanted to be. I envision my process of decolonisation to take the form of 'Coloured' consciousness. I define 'Coloured' consciousness as an awareness of being legally classified as 'Coloured' and being conscious of the artificial tropes of inhumanity assigned to this legal identity. This 'Coloured' consciousness as I have termed it, calls for the critical use of 'Coloured' and the rejection of this legal classification as bearing no truth but promoting stereotypes. More importantly, 'Coloured' consciousness speaks to the rejection of 'Coloured' women as homogenous and having questionable humanity. Since 'Coloured' is automatically tied to colonial and apartheid evils, the need to decolonise ultimately speaks to the eradication of the legal classification and allowing men and women suppressed under this classification to be liberated. This is why decolonisation is imperative for me and my identity. Based on this, 'Coloured' con-sciousness is an essential part of the decolonization process for me and serves to liberate 'Coloured' women such as myself, from racialisation and inhumanity.

MAART: What is the way forward for you as a psychologist in the country and as someone who is existentially grappling with the aftermath of apartheid classification on your personal being?

ARENDSE: In reflection on my identity, the construction and use of 'Coloured' as a legal classification has not only hidden the moral and injustice on which colonialism and apartheid was built but created justification for dehumanising those under this classification. The apartheid government created a system of dehumanisation and legalised who was considered human. Those deemed as less than human needed to be policed and controlled. Within this, even my gender as a 'Coloured' woman was racialized and policed. Although apartheid ended, the racialised and gendered attributes from apartheid still inform how men and women respond to me as a 'Coloured' woman. The reproduction of apartheid notions of me as a 'Coloured' woman is how oppressive systems continue to exist and are perpetuated in society. The 


\section{Danille Elize Arendse}

entire premise of creating the 'Coloured' classification was therefore to ensure that those classified as such would know that they are not fully human. They may have acquired some features similar to those deemed as humans (white men and women) but this did not translate to humanness (Snaza \& Tarc 2019; Mendez 2015; Lugones 2010; Wynter 2003). As Ramose (2019) points out, the justifications and apparent truths informing our history is burdened with morality. The justifications for apartheid and creating the 'Coloured' classification should therefore also be viewed as the concealing and suppression of truth. In essence, the continuous legalisation of 'Coloured' disregards our equality as humans and communicates the refusal of seeing those labelled as such as human beings (Ramose 2019; Wynter 2003).This does not mean that new meanings and values cannot be attached to 'coloured' but only in as far as an ethnic identity. In truth there is no race such as 'Coloured' and there never was prior to the interpretation, constructions and labelling of colonisers and apartheid-enforcers. The way forward for me as a psychologist in South Africa is to think about the importance of 'Coloured' consciousness. My consciousness through decoloniality requires me to question the knowledge that had been presented to me as truth and that had never truly served me. It only served to silence me and make me complicit in my own oppression (Gordon 2020a; 2020b; Maart 2020a; 2020b; Ramose 2020 Wynter 2003). I believe that it is important to grapple with your identity and how you wish to be identified. 'Coloured' women are then free to decide their identity and not be subjected to predetermined stereotypes incorporated under a fictitious legal classification. This would be the start of re-humanising, which would involve learning to be human after suffering under dehumanising practices such as the 'coloured' classification (Ramose 2019; Wynter 2003). As a result, I see myself as entering a journey of decolonial thinking and as constantly evolving in how I think about myself and my identity. I don't believe my way of seeing 'coloured' should be seen as universal, but it should offer a perspective on the aftermath of the apartheid classifications. In my personal capacity, I want to continue to engage in dissecting 'coloured' identity and the different nuances prevalent in South Africa.

MAART: Has the Decolonial Summer School assisted this process in any way?

ARENDSE: The confidence with which Professors Gordon, Ramose and 
Maart communicated their knowledge of decoloniality spoke to their wisdom and innate nature of teaching. The concepts were not prescribed but rather offered for interpretation. There was no uniformity in how one should decolonise or to what decoloniality should be because our context is the determining factor when deciding to engage in decoloniality. This was perhaps the most profound aspect for me, as I had become accustomed to prescriptions of how theory should be used and that deviating from this, renders it useless. They advocated the notion that I was a producer of knowledge instead of a perpetual student (Gordon 2020a; 2020b; Maart 2020a; 2020b; 2014a; Ramose 2020; Ramose 2019). In my experiences during the Decolonial Summer School, there are obvious parallels with previous experiences I have had because of my 'Coloured' appearance. The difference between these experiences was that there was no need for me to dismantle the stereotypes or perceptions at the summer school interactions. There was something in the teaching and education of the Decolonial Summer School that had allowed the [previously mentioned] black woman to recognise me as a fellow black woman. We had been colleagues for a while and somehow, she had never regarded me as a black woman or as someone that she shared mutual struggles with before the summer school. In this instance, decoloniality had facilitated belonging. It had created black solidarity among us merely by being part of the summer school. What was it about the Decolonial summer school that allowed her to see me beyond my appearance? I had not changed in terms of my appearance, but her interpretation of my appearance had changed. This drew me to question the central messages of the summer school. The teachings were not only educational, they were facilitating change. They required us to recognise how coloniality was operating to separate us as black women and more importantly, coloniality was allowing us to accept our sub-humanity due to our racialised and gendered existence. Decoloniality advocated for a shift in thinking that transcended the grips of colonial knowledge. This forced us to question what we had come to know as truths and to inspect how we were upholding colonial notions of humanity (Gordon 2020a; 2020b; Maart 2020a; 2020b; Ramose 2020; Snaza \& Tarc 2019; Wynter 2003). Furthermore, critical consciousness was raised and shared during the summer school. The Decolonial Summer School also forced us to inspect how White supremacy had created racial classifications as part of the divide and rule strategy and through our acceptance of these classifications, we were complicit in our own oppression (Gordon 2020a; 2020b; Maart 2020a; 2020b; Ramose 2020). This 


\section{Danille Elize Arendse}

also brings me to the separation of black and 'Coloured' women that was enforced by apartheid. There were no substantial differences, only colonial and apartheid laws that ingrained these differences. This corresponds to how my similarity in appearance with the Brazilian men and women did not ostracise but invite belonging and acceptance. Racial mixing and mixed heritage had been labelled with negativity only to discourage interracial relations. Witnessing how easily the Brazilian woman had claimed her Blackness was inspiring to me. It had allowed me to see how I was still subjecting myself to the confines of the 'Coloured' classification. I was black in attitude and thinking but was scared to openly voice it. In seeing how she claimed her Blackness, it facilitated the unshackling of my closeted Blackness because men and women had always subjected me to only being a 'Coloured' woman. There was perhaps a hidden curriculum present in the summer school, that of emancipation and recognition of being already fully human. My Blackness did not need to conform to the colonial conceptions of Blackness, but instead could be a Blackness that was inclusive of my diversity. My Blackness had a language of its own and through decolonial thinking, I was able to celebrate this unconventionality.

\section{Conclusion}

This article focused on my personal experiences of being classified as a 'Coloured' woman in South Africa through the legalised system of classification. My reflections, through the question and answer format, were particularly important after attending the 2020 Decolonial Summer School. During and after engaging with the issues raised during the summer school, I felt a sense of agency to redefine myself through decolonial eyes. It was through the recognition of my oppression and my complicity in this oppression that I found the courage to dismantle systems of subordination that were not serving me. I reflected on the inhumanity I have encountered with my legal classification through 'Coloured' consciousness, and why being critical of this legal classification is imperative. I also contrast these experiences with the experiences I had with conference members that transitioned in their thinking and understanding of me. My experiences during post-apartheid South Africa have demonstrated that there are damaging internalised knowledges regarding 'Coloured' women that require active decolonising. It is with this in mind that my intention is not to be recognised or affirmed, but rather to make the 
invisible, more visible and in so doing, give a voice to the silenced narratives. I am encouraged to build a future where I belong and that celebrates my difference. I believe that engaging in my narratives as a 'Coloured' woman, whose humanity has been questionable, I am able to challenge the truths forced upon me and reclaim my humanity. The replication of coloniality and apartheid through the 'Coloured' classification demands that we become conscious of practices that dehumanise or else we become agents of oppression ourselves. Through a 'Coloured' consciousness, we become critical of the legal classification of 'Coloured' and allow those labelled as such, to take back their agency and shift their narrative in more constructive ways. More importantly, this 'Coloured' consciousness speaks to decolonizing and re-humanizing 'Coloured' women whose intricate Blackness has been shaped by colonialism and violence.

\section{References}

Adhikari, M. 2006. Hope, Fear, Shame, Frustration: Continuity and Change in the Expression of Coloured Identity in White Supremacist South Africa, 1910 - 1994. Journal of Southern African Studies 32, 3: 468 - 487. https://doi.org/10.1080/03057070600829542

Ahluwalia, P. \& A. Zegeye. 2003. Between Black and White: Rethinking Coloured Identity. African Identities 1, 2: 253 - 280. https://doi.org/10.1080/1472584032000173139

Boswell, B., Z. Erasmus, S. Johannes, S. Mahomed \& K. Ratele 2019. Racist Science: The Burden of Black Bodies and Mind. The Thinker: A PanAfrican Quarterly for Thought Leaders 2019, 81: 4 - 8.

Crenshaw, K. 1994. Mapping the Margins: Intersectionality, Identity Politics and Violence against Women of Colour. In Fineman, M.A. \& R. Mykitiuk (eds.): The Public Nature of Private Violence. New York: Routledge.

Dalmage, H.M. 2018. Mixed Race Families in South Africa: Naming and Claiming a Location. Journal of Intercultural Studies 39, 4: 399 - 413. https://doi.org/10.1080/07256868.2018.1484348

Ellis, C., T.E. Adams \& A.P. Bochner 2010. Autoethnography: An Overview. Historical Social Research 12: 273 - 290.

Erasmus, Z. 2011. Creolization, Colonial Citizenship(s) and Degeneracy: A Critique of Selected Histories of Sierra Leone and South Africa. Current 
Sociology 59, 5: 635 - 654. https://doi.org/10.1177/0011392111408678 Fanon, F. 1986. Black Skin, White Masks. London: Pluto Press. Gordon, L. 2020a. Identity, Freedom, Liberation and Justification. Presentation at the Decolonial Summer School, 13 - 17 January 2020.

https://doi.org/10.29086/2519-5476/2020/sp33a12

Gordon, L. 2020b. Decolonization, Decoloniality and Philosophy of Liberation. Presentation at the Decolonial Summer School, $13-17$ January 2020, Pretoria, South Africa.

Gordon, L. 2010. Fanon on Decolonizing Knowledge. In Hoppe, E.A. \& T. Nicholls (eds): Fanon and the Decolonization of Philosophy. New York: Lexington Books.

Isaacs-Martin, W. 2018. Minority Identities and Negative Attitudes toward Immigrants: Prejudice and Spatial Difference amongst the Coloured Population in South Africa. African Review 10, 1: 41 - 57.

https://doi.org/10.1080/09744053.2017.1399562

Josias, A. 2015. Diasporic Double Consciousness, Creolite and Coloured Identity: Perceptions and Beliefs of Coloured Professionals in South Africa. Unpublished Masters thesis. University of Cape Town, South Africa.

Lugones, M. 2010. Towards a Decolonial Feminism. Hypatia 25, 4: 742 - 759. https://doi.org/10.1111/j.1527-2001.2010.01137.x

Maart, R. 2020a. When Black Consciousness, Psychoanalysis and Derridean Deconstruction Meet Critical Race Theory. Presentation at the Decolonial Summer School, 13 - 17 January 2020, Pretoria, South Africa.

Maart, R. 2020b. Who is the Decolonial Subject. Presentation at the Decolonial Summer School, 13 - 17 January 2020, Pretoria, South Africa.

Maart, R. 2014a. When Black Consciousness Walks Arm-in-arm with Critical Race Theory to Meet Racism and White Consciousness in Humanities. Alternation 21, 2: 54 - 82.

http://alternation.ukzn.ac.za/Files/docs/21.2/04\%20Maa.pdf

Maart, R. 2014b. Race, with Emphasis on South Africa. Sociology: A South African Introduction. South Africa: Cengage Learning.

Martin, D. 1998. What's in the Name Coloured. Social Identities 4, 5: 523 541. https://doi.org/10.1080/13504639851753

Mendez, X. 2015. Notes toward a Decolonial Feminist Methodology: Revisiting the Race/ Gender Matrix. Trans-Scripts 5, 2015: 41 - 59.

Nieuwoudt, S., K.E. Dickie, C. Coetsee, L. Engelbrecht \& E. Terblanche. 
2019. Age- and Education-related Effects on Cognitive Functioning in Coloured South African Women. Aging, Neuropsychology, and Cognition $1-17$.

https://doi.org/10.1080/13825585.2019.1598538

PMid:30922209

Ramose, M. 2020. A Philosophical Investigation into the Conceptual History of Decolonization in Africa. Presentation at the Decolonial Summer School, 13 - 17 January 2020, Pretoria, South Africa.

Ramose, M. 2020. Critique of Ramon Grosfoguel's 'The Epistemic Decolonial Turn. Alternation 27,1: 271 - 307. https://doi.org/10.29086/25195476/2020/v27n1a14

Shefer, T., A. Strebel, S. Ngabaza \& L. Clowes 2018. Student Accounts of Space and Safety at a South African University: Implications for Social Identities and Diversity. South African Journal of Psychology 48, 1: 61 72. https://doi.org/10.1177/0081246317701887

Snaza, N. \& A.M. Tarc 2019. 'To wake up our minds': The Re-enchantment of Praxis in Sylvia Wynter. Curriculum Inquiry 49,1: 1 - 6. https://doi.org/10.1080/03626784.2018.1552418

Wynter, S. 2003. Unsettling the Coloniality of Being/ Power/ Truth/ Freedom: Towards the Human, after Man, its Overrepresentation - An Argument. CR: The New Centennial Review 3, 3: 257 - 337.

https://doi.org/10.1353/ncr.2004.0015

Danille Elize Arendse Research Associate and Research Psychologist Department of Psychology

University of Pretoria Pretoria arendse.danielle@gmail.com 